\title{
Images of Entrepreneurship Using Drawing to Explore Entrepreneurial Experience
}

\author{
Clarke, Jean; Holt, Robin
}

Document Version

Accepted author manuscript

Published in:

Journal of Business Venturing Insights

DOI:

10.1016/j.jbvi.2019.e00129

Publication date:

2019

License

CC BY-NC-ND

Citation for published version (APA):

Clarke, J., \& Holt, R. (2019). Images of Entrepreneurship: Using Drawing to Explore Entrepreneurial Experience. Journal of Business Venturing Insights, 11, [e00129]. https://doi.org/10.1016/j.jbvi.2019.e00129

Link to publication in CBS Research Portal

\section{General rights}

Copyright and moral rights for the publications made accessible in the public portal are retained by the authors and/or other copyright owners and it is a condition of accessing publications that users recognise and abide by the legal requirements associated with these rights.

Take down policy

If you believe that this document breaches copyright please contact us (research.lib@cbs.dk) providing details, and we will remove access to the work immediately and investigate your claim. 


\title{
Images of Entrepreneurship: Using Drawing to Explore Entrepreneurial Experience
}

\author{
Jean Clarke and Robin Holt
}

Journal article (Accepted manuscript*)

\section{Please cite this article as:}

Clarke , J., \& Holt, R. (2019). Images of Entrepreneurship: Using Drawing to Explore Entrepreneurial Experience. Journal of Business Venturing Insights, 11, [e00129]. https://doi.org/10.1016/j.jbvi.2019.e00129

DOI: https://doi.org/10.1016/j.jbvi.2019.e00129

* This version of the article has been accepted for publication and undergone full peer review but has not been through the copyediting, typesetting, pagination and proofreading process, which may lead to differences between this version and the publisher's final version AKA Version of Record.

Uploaded to CBS Research Portal: July २०२०

(C) 2019. This manuscript version is made available under the CC-BY-NC-ND 4.0 license http://creativecommons.org/licenses/by-nc-nd/4.0/ 


\title{
Images of Entrepreneurship: Using drawing to explore entrepreneurial experience
}

\begin{abstract}
Entrepreneurship is a generative and transformative process of altering convention where personal/social history, assets, technologies, and trading activity are gathered in organizational form. How entrepreneurs frame this process, and are, in turn, organized, constitutes the entrepreneurial experience. Typically this framing has been researched using narrative methods: how entrepreneurs tell their stories. In this paper we develop an emerging branch of inquiry challenging a sole focus on linguistic narrative in favour of asking entrepreneurs to use drawings to illustrate their venture. In other disciplines drawing is a recognised tool for eliciting in-depth and latent information. We argue it deserves more attention in entrepreneurship research. We show some indicative drawings created by entrepreneurs and highlight some of their reflections on the experience. A drawing is a partial, direct and imaginative expression of entrepreneurial experience rather than a reasoned, historically linear story. In this sense it is less complete, and, we argue, more akin to entrepreneurship itself.
\end{abstract}

\section{Keywords}

Entrepreneurial experience, drawing, images, venture creation 


\section{*INSERT IMAGE ONE ABOUT HERE*}

\section{Introduction}

The field of entrepreneurship has increasingly been interested in stories entrepreneurs use to talk about and make sense of their life-business-narratives. Existing research has shown entrepreneurs use narratives to justify their goals in creating an organization, to persuade others of its viability, and to control and make sense of the ambiguity inherent in the entrepreneurial environment (Downing, 2005; O'Connor, 2002: Rae, 2002; Cohen and Musson, 2001; Hjorth and Steyaert, 2004). What we know less about are the narratives of entrepreneurial experience or what the moment-to-moment lived experience of entrepreneurship is like from the perspective of the entrepreneur (Byrne and Shepherd, 2915). Researchers are recognizing that focusing on the ongoing experience of entrepreneurs is central to our understanding of the nature of venture creation (Sarasvathy, 2004; Shepherd, 2003). As Morris et al, (2012, p.11) note since entrepreneurship is "largely unscripted, unpredictable, and uncontrollable [its] richness...lies in how it is personally experienced". Sensing how entrepreneurs experience their world remains under-developed, requiring as it does methods by which passion, imagination and emotion, as well as the nascent and elusive sense of opportunity, might be conceptualized, without traducing the phenomenon under inquiry (Cardon et al, 2013; Dimov, 2011).

Asking entrepreneurs to verbally construct narratives of lived experience is certainly one approach to gaining insight. However, some research suggests that for complex, dynamic and multidimensional experiences like entrepreneurship, it can be difficult for participants to tell stories "that go beyond a mere shopping list of facts, distracted ramblings, or disjointed vignettes to enter a space of deeper reflection" (Guanette and Marshall, 2009; Holt and Clarke, 2017). Narrative representations are 
bounded by a linear logic, in that words are typically organised in temporal arrangement one following another and order of sequence is important (Kress, 2004). Yet as Kramer (2000, p.85) notes human experiences that are complex, subjective and constantly changing "often do not lend themselves to linear and rational modes of thinking. They may require alternative modes of representation, such as imagery, art, metaphor and non-linear 'logic"'. Images, in particular, are intrinsically nonlinear, governed by the logic of space and simultaneity rather than time, allowing for a more holistic, concurrent representation of concepts, emotions and information without the need to prioritize and carefully place certain elements along a temporal continuum to ensure a cogent story of cause and effect (before/after) (Kress \& van Leeuwen, 2002). Images allow simultaneous expression of disparate thoughts and ideas (Arnheim, 1969; Broussine, 2008; Gauntlett, 2007), as one entrepreneur relayed to us in using this methodology “a picture can say 1000 words can't it? That's what mine says".

In this paper we introduce drawings as a way to access this non-linear, holistic understanding of entrepreneurial experience by asking entrepreneurs to draw an image of their organizational venture. Take, for example, the image above of a rollercoaster, drawn by an entrepreneur in 2016. The sharp curves and steep inclines illustrating his experience of entrepreneurship a process that is full of "twists and turns", "white knuckle rides, falling and clinging on hard" "unexpected drops and amazing highs” (Lichtenstein et al., 2007). As Rawson (1969) notes ‘a drawing’s basic ingredients are strokes or marks which have a symbolic relationship with experience, not a direct, overall similarity with anything real'. Drawings, we argue, are especially suited to revealing images of being in business because they are incomplete, yet generative and affectively embodied rather than clinically reasoned (Dantzic, 1999). They offer an authoring space for self, as entrepreneurs make choices 
about how they represent the process of entrepreneurship and the aspects of their experience that they represent as salient or significant (Tovey, 2010). Through the process of visual conceptualization, and the reflective discussion of these images with the researcher, participants are given an expressive channel to voice their inner stories in a way that encourages active conceptualisation and contemplation (Gauntlett, 2007). The meaning of the images "resides most significantly in the ways that participants interpret those images, rather than as some inherent property of the images themselves' (Stanczak, 2007, p. 11). Drawings force the researcher and subject alike to acknowledge the struggle with meaning, and its partial and felt condition; they are ideal tools for apprehending the incomplete and passionate entrepreneurial condition (Ingold, 2007).

\section{Drawing Entrepreneurial Experience}

In his phenomenological study Rosand (2002, p.1) recognizes drawing as the fundamental pictorial act, stating "to make a mark or trace a single line upon a surface immediately transforms that surface, energises its neutrality; the graphic imposition turns the actual flatness of the ground into virtual space translates its material reality into the fiction of the imagination." Drawing is a form of visual art in which an individual uses various drawing instruments such as graphite pencils, pens, charcoal etc. to make non-standardised visual representations on paper or another appropriate material. Drawing pre-dates written language and is a universal form of human expression used to "interpret, examine, record and transform our experiences" (Stiles, 2014). It remains “an important means of creative development, exploration and achievement... extensively encouraged if not taught in education" (Taylor, 2008). Drawing is a central activity in the work of artists, designers, architects and engineers, a tool used for creative exploration that enables the visualization and development of 
ideas. It is also increasingly of interest to a range of non-image based disciplines including history, psychology, anthropology and education as an empirical method where drawings can help both researchers and participants to articulate ideas and understandings in ways that verbal or written language may not offer (Afonso, 2004; Guillemin, 2004; Hendrickson, 2008; Kearney and Hyle, 2004; Mitchell, 2006). Despite advancements in the use of drawing in other social science disciplines, organizational research and more specifically entrepreneurship research has yet to fully embrace the potential benefits of this methodology. In spite of the promise of drawing research methods and the call by scholars to use them there is limited research leveraging these tools (Clarke and Holt, 2017).

In methodological terms how can such drawings be collected in entrepreneurial contexts? Research has shown that when asked to draw an image that illustrates their venture, entrepreneurs initially struggle (see Clarke and Holt, 2017). To draw a venture is to draw something that is not an object, it does not exist outside of the situation of its expression. What marks my business out? What makes it what it is? Why does it matter that it exists? Relatedly, they can struggle with lack of technique, wanting to produce a good drawing, but admitting their lack of skill. To allay such frustration, when using this methodology with entrepreneurs we highlight that we are not so interested in artistic technique, but in their using the experience to distil and express their sense of being-business. We aim to get at their expertise as entrepreneurs, not artists, so what is of interest is the way in which the entrepreneurs choose to represent or express their understanding of their entrepreneurial experience through their drawings. It the decisions and choices that they made in the composition of the drawings, rather than the artistic techniques they display, that provide the material for analysis alongside the verbal explanations from the entrepreneurs of what 
the drawings mean. Unlike interviews where an instantaneous response is expected, in a drawing based methodology participants are given time for reflection and the opportunity to create a more nuanced depiction of lived realities.

The examples of entrepreneurs' drawings that we use in this paper were created with paper, graphite pencils and charcoal. ${ }^{1}$ Colours and different media like acrylic paint could also be used perhaps prompting a different type of fluidity in working at images (Eindhoven and Vinacke, 1952). Entrepreneurs should be give space and time to create their images, approx. 30-60 minutes, as the process of drawing necessarily involves reflection, experiment and starting over. Following the creation of the drawing, there are various approaches for gaining access to entrepreneurs' verbal understandings of their drawings. Some have employed group discussions of the drawings directly following the creation of the drawings as a means to evoke immediate and collective reactions (e.g. Vince and Broussine, 1996; Vince and Warren, 2012). Others suggest immediate verbalisation of the images can result in verbal overshadowing and limit the understandings created by the images. In order to avoid this individual interviews are conducted several weeks after the initial drawing session (Clarke and Holt, 2017; Kantrowitz, 2012). In our study the drawings were created two to four weeks prior to the interviews with entrepreneurs about the images. The approach taken will depend on the precise research question of the study and no matter what approach is used the important issue is to ensure that entrepreneurs reflect deeply on their drawing and its relation to their experience of creating ventures.

\footnotetext{
${ }^{1}$ The illustrative drawings and quotes come from a cohort of entrepreneurs running potentially high growth entrepreneurial businesses attending an educational programme allowing them to interact with academics and business experts to facilitate and catalyse such growth
} 
In terms of analysis, much of the focus is on meanings participants themselves derive from the images i.e. the comments accompanying the drawing (Kress, 1997; Vince and Broussine, 1996). The drawings and talk should be treated not as separate entities but rather as intertwined aspects of the process of meaning-making (Wright, 2007). Although a critique could be that we are once again returning to linguistic narratives of entreprneuerial epxerience, the intent is to allow entrepreneurs to return to their visual understandings and explain and elaborate on them. It is therefore important that the researcher does not attempt to "interpret" the meaning of the drawings without input from participants and but rather act as a facilitator ensuring that any meaning-making is sensitive to the province of the participant (Kearney and Hyle, 2004). The approach has been heralded for its emancipatory potential given the collaborative role participants play in the process (Wang \& Burris, 1994; Warren, 2005) ensuring the researcher does not "force informants into his or her cognitive framework" (Meyer, 1991, p. 232). In a recent drawing study conducted in the context of entrepreneurship Clarke and Holt (2018) draw on the social semiotics and visual grammar literature (Halliday, 1994; Kress and Van Leeuwen, 1996; Kress and Van Leeuwen, 2006). Their aim was not to replace the participants' interpretation of the drawings but rather to offer an analytical framework and vocabulary through which to discuss the visually specific ways images realize meaning. Therefore, the focus in drawing studies is always on the participants' interpretation of the images, however, specialist visual literatures such as semiotics may be drawn on to help researchers uncover how participants visually achieve salience in imagery.

Below we outline two aspects of drawing, what we refer to as "beginnings" and "traces", ones we feel germane to understanding how this medium may be used and be useful in understanding entrepreneurial experience. 


\section{Beginnings}

Drawings embody beginnings by which we mean disclosing something new, an opening up of form whose unity arises in having been worked through. Rather than delineate things a drawing suggests them, through the process a drawer is striving after ideas and possibilities by which something can be brought into substance. The strokes and stops are the first steps toward the fabrication of something lasting, but what is lasting is only hinted at, and the drawing itself remains suggestive. Amid the lines, smudges and blank spaces where beginnings cohere, but nothing is fixed, and where typically there is no definitive end, meaning is fleeting, dissolved and held in suggestive spaces in which what Merleau Ponty (1994) calls the labour of vision is undertaken. There is an affinity here between the beginning that is a venture and the beginning constituted in a drawing: the process of entrepreneurial emergence (Gartner et al, 1992) the opening up of a new organizational form or space (what Spinosa et al 1997 call disclosing).

In terms of using drawing as a methodology with entrepreneurs, drawings are powerful because of their "ability to be a holding ground and negotiation space for both explicit and yet-to-be-made-explicit knowledge that allows them to be more than the sum of their parts" (Henderson, 1999, p.). Drawing can aid entrepreneurs' understanding of the complexity around them offering the potential for a deliberate vagueness or incompleteness, which supports abstract, transformative and generative thinking (Rawson, 1969). As Garner (2008) notes, engaging in drawing can be a way of embracing the unknown, accepting challenge and rejecting the comfortable. Using a drawing methodology with entrepreneurs offers them a thinking space where they can begin to add meaning and make sense. Therefore drawing is "not a space in which thought is represented but rather a space where thinking is presenced" (Rosenberg, 
2008). A number of entrepreneurs expressed how instrumental drawing was in terms

of developing their thinking about their venture when they were subsequently

interviewed about their drawings. As one entrepreneur, specialising in online

education, outlined:

It's helped me clarify my thoughts and it has helped me say it is so useful sometimes just to sit back and look at something and think about it...the real balanced business is the one that sits back and says what are we doing and where are we going and what is this thing about (Online Education Entrepreneur).

Another entrepreneur noted:

[The process of drawing is] really good because it makes you think about what [being an entrepreneur] actually does mean... when you are actually forced to think about it, it does make you think about a lot of things (Web and Mobile Communications Entrepreneur).

The entrepreneur who drew Image 2 below also reflects on the way the creation of the image allowed him to more clearly express what his experience of being in business:

\section{*INSERT IMAGE TWO ABOUT HERE*}

I guess I am the orchestrator, the conductor and sometimes the composer...my role is to tell a story to an audience and I suppose that made me think well actually that is what we do and ultimately it is about putting our clients on to a stage whether it be media, television, radio, articles whatever, and the sketch just emanated from that really. And then the idea came after drawing "a stage" that I wanted to embellish it trying to create the shadows and show that [the clients] are in the spotlight...this is probably the first piece of art I properly had to come up with since probably being at school and college, I mean I've got two boys and we do scribble around with them but trying to come up with this sort of idea was, you know different and quite enjoyable actually....

This echoes Guillemin's observation (2004: 274) "the word drawing is both a noun and a verb; it is both a product and a process." Drawings are both physical and mental and allowed the entrepreneurs to think with, and through drawing to reveal possibilities that give course to ideas, and to help fashion their eventual form 
(Rosenberg, 2008). In drawing images emerge as a result of an intricate collaboration between the hand and the drawer's mental space, the act of drawing itself therefore can often give rise to an image or an idea. As Pallasmaa (2009, p.) argues, when drawing "the hand is in a direct and delicate collaboration and interplay with mental imagery. The image arises simultaneously with an internal mental image and the sketch is mediated by the hand". The entrepreneur, who drew Image 3 representing the Mandelbrot set, reflected on his experiences of being-in-business as both chaos and simultaneous order. He highlighted during his interview his uncertainty about whether he realized this was experience through drawing the image or whether he was already aware that this was his experience before drawing the image:

\section{*INSERT IMAGE THREE ABOUT HERE*}

I used to be really into chaos theory when I was a teenager and just the idea, the butterfly effect, the idea that a tiny change in one area can make an enormous change in another area. So the analogy being that a flap of butterfly's wings in China could change the way the system is in America. Chaos comes out of order, and order comes out of chaos, so it's all about tweaking those small things... It's order in chaos isn't it, and that fits well on so many levels...the question is though, for me anyway, did I make that up because it's a drawing, or did I think of it before I drew it. I don't know. (Software Entrepreneur)

As we see in the example above the strength of a drawing is found in its own expression, not in what it distils and represents as an object or even idea.

It is in mapping and illustrating our experience on paper through signs and symbols that we being to discover new ways of seeing. A drawing is therefore a thing of quality rather than quantification, containing within itself human experience elaborated upon by a unique individual expression of mine-ness, a unity (Gestaltung) that resists logic and calculation (Klee, 1961/1979: 16).

\section{Traces}


To imagine possibilities by posing beginnings, drawings also enlist what is already there: they are connections to or traces of present surroundings. The artist John Constable spoke of how his thousands of sketches matured under the shifting play of repetition: he spent hours each week sketching clouds, for example, learning their forms within the restless environment, attending to their atmospheric effects. Constable observed that in nature "no two days are alike, nor even two hours; neither were there ever two leaves of a tree alike since the creation of the world" (Constable, 1835/1951: 273). Only by being in the open, ever-sensitive to his surroundings, repeating and retracing was he able to produce work both original but also familiar.

New spaces emerge from old ones; hence the process of drawing is not just imagining what could be, but evoking/representing or tracing what already is. Drawings defer to what exists, but they don't simply imitate, they add something: they conform and diverge (Wolf and Perry, 1988). This aligns with the entrepreneurial experience since persuading others such as employees, customers and funders of the cogency, attractiveness and viability of his ideas for his venture is an exercise in being alive to and connecting to the conditions and motivations of this varied audience. Entrepreneurs must tread a fine line between copying conventions and standards in order to be seen as legimate within their cultural context whilst at the same time ensuring they are distinctive enough to warrant interest and investment (Navis and Glynn, 2011). The venture is bound by the entrepreneur's sensitivity to conditioning constraints: the social and technological orders into which any entrepreneur is thrown. This point is made by a female PR entrepreneur below:

*INSERT IMAGE FOUR ABOUT HERE*

It is all kind of fluid, everything feeds in, you need everything in order to make it happen if that makes sense... a continuous flow I think...just a single component wouldn't ever kind of give you enough you need everything. It's all 
well and good having ideas but the good ideas that you have, have to spark, like the really good ones you need the insight of what the people want, the target audience, client, whatever, when you can connect those that's when the kind of sparks happen I think.

Evidence of these "traces" or connections with their wider context emerges in how the drawings are utilised by the entrepreneurs. They not only served as thinking tools for the entrepreneurs, but also once the drawings were captured on paper they could work as collaborative tools to be further analysed, refined and negotiated with others in their surroundings. As Henderson (1999) shows drawings can work as flexible boundary objects that allow people with perhaps different or conflicting insights or understandings to work together towards some common endeavour. One entrepreneur spoke of hanging his completed drawing on his office wall and using the drawing as a means to connect with those around him and to express him goals using a visual form. The drawing was being used partly as a personal spur, partly as a public declaration:

I think a picture is a conversation piece sometimes isn't it, a piece of art or a picture you know, you have that on the wall and people will go 'What is that all about?'...the more times you express your story to other people, the more determined it makes you to actually achieve what you've actually set out to do, the more you keep your secrets inside you then I think it is easier to let them be trampled - (Event Entrepreneur)

Another entrepreneur similarly expressed how the image he created during the drawing exercise gathered what he was trying to achieve in a way that was succinct and presented a outline or "blueprint" for the venture's future:

I am going to stick it up on the wall now, I rather like it, is going to be like a motiffor carrying on you know keep it as simple as this drawing. And as happy as this drawing so it's like a kind of blueprint. (Energy Entrepreneur) 
The entrepreneur who drew Image 4 similarly discusses the simplicity and clarity of his visual "motif" which meant others could be brought into the image.

\section{*INSERT IMAGE FIVE ABOUT HERE*}

I tried to think in simplistic terms and [this image] seemed just to click when I was doing this it represents moving from one state of perplexity if you like, to one state of, happiness would be the wrong word but enlightenment, perplexity to enlightenment is probably quite a good way of describing it..I quite like it, it seems to work very well with me, resonates with me and it is simplistic and I think people possibly might understand easily what it means. (Management Leadership Entrepreneur)

The drawings capture something about the entrepreneurs' world but also expose us to what is yet to be formed, giving a sense both of how things are and might be

(Merleau-Ponty, 1994: 145). This is illustrated by this female entrepreneur below who ran a video production company, the images allow the entrepreneurs to express what matters most in their venture, to find what marks it as distinctive but also to show in show where the possibility of opportunity lies.

\section{*INSERT IMAGE SIX ABOUT HERE*}

Everybody has a story really and you know it is up to us to get those stories out of the people themselves but also to portray the stories through film as well...looking at the eye in the image I drew it looks quite feminine and I suppose what I do in the business is the people focus stuff...that's primarily my role, kind of drawing out the stories, engaging with people...you'll get some companies that are too focused on the quality of the output and haven't listened and understood what the customer wants or what the audience needs to hear, and then you'll get other companies that listen but don't have the creativity to put something high quality together but I think we can probably do all of that.

In examining existing habits and forms entrepreneurs find a provocation for actively envisaging the generation of new potentialities and spaces (McMullen and Dimov, 2013). Investigating entrepreneurship through drawings reveals what typically gets 
overlooked, namely understanding entrepreneurship as an experiential, imaginative re-composition of constraints as possibilities (Packard, 2017).

\section{Conclusion}

In this paper we argue that drawing can be a way to access the experience of being an entrepreneur since drawing is 'a critical and reflective form of investigating ourselves and the way we encounter the world around us' (Garner, 2008: 17). We have shown how asking entrepreneurs to draw images of their ventures gives them the space and opportunity to reflect on the meanings they attribute to their entrepreneurial experience. Their responses to the activity show that the use of the drawings can prompt active participation in the research process but also enhance the capacity of research participants to make sense of, and attribute meaning to, events and experiences (Meyer, 1991). The process of drawing allowed the opportunity for the entrepreneurs to not only reflect but also create understandings about their venture.

The drawings also loosen and push back at the concepts of entrepreneurial theory, refusing easy academic habits whilst encouraging entrepreneurs to reflect on theirs. Like drawings, the creation of the venture which is underway and being carried into being cannot be known in a complete way, yet it changes the condition of things (Schumpeter, 1947). An entrepreneur organizes a venture in an imaginative frame of propensities that can be felt and argued for very intensely, and which evokes possibility and enthusiasm in others; it is 'as if' it exists (Gartner, 1993; Nicolson and Anderson, 2005). Being nascent is not to say either a drawing or venture lacks force. Though, like the venture, a drawing refuses the full weight of completeness, the lightness and briefest of suggestive touches can carry with it the most pregnant of meaning. 
Drawing has the potential to be used for a wide variety of future research questions in the context of entrepreneurship not only entrepreneurial experience as we have examined here, but also for example entrepreneurial identity and emotion in the context of entrepreneurship. Although drawing is often considered an individual activity, collective drawing could also be used with the entrepreneurs and those in their environment, or entrepreneurial teams, as a methodology to explore issues such as the development shared cognition, emotional expression and sensemaking.

\section{References}

Arnheim, R., 1969. Visual Thinking. Berkeley, LA: University of California Press.

Broussine, M. 2008. Creative methods in organizational research. London: Sage.

Cardon, M.S., Gregoire, D.A., Stevens, C.E., Patel, P.C., 2013. Measuring entrepreneurial passion: conceptual foundations and scale validation. J. Bus. Ventur. 28, 373-396.

Clarke, J., 2011. Revitalizing entrepreneurship: how visual symbols are used in entrepreneurial performances. J. Manag. Stud. 48, 1355-1391.

Clarke, J. and Holt, R. (2017). Imagery of ad-venture: Understanding entrepreneurial identity through metaphor and drawing. J. Bus. Ventur. 32, 474-497.

Cohen, L. and Musson, G., 2000. Entrepreneurial identities: reflection from two case studies. Organ. 7(1), 31-48.

Constable, J. 1835/1951 Papers in C.R. Leslie (ed.) Memoires of the life of John Constable. London: Phaidon Press.

Dantzic, C. M., 1999. Drawing Dimensions: A Comprehensive Introduction. Upper Saddle River, NJ: Prentice-Hall.

Dimov, D., 2011. Grappling with the unbearable elusiveness of entrepreneurial opportunities. Enterp. Theory Pract. 35 (1), 57-81.

Ehrenzweig, A. 1965. The psychoanalysis of artistic vision and hearing. New York: George Braziller.

Ehrenzweig, A. 1967. The Hidden Order of Art. Study in the Psychology of Artistic Imagination. London: Weidenfeld and Nicolson. 
Eindhoven, J. E. and Vinacke, W.E. 1952. Creative processes in painting. Journal of General Psychology, 47, 139-64.

Garner, S., 2008. Writing on Drawing: Essays on Drawing Practice and Research. Chicago: University of Chicago Press.

Gartner, W.B., 1993. Words lead to deeds: towards an organizational emergence vocabulary. J. Bus. Ventur. 8 (3), 231-240.

Guillemin, M., 2004. Understanding illness: Using drawings as a research method. Qual. Healt. Res. 14(2), 272-287.

Hjorth, D., Holt, R., Steyaert, C., 2015. Entrepreneurship and process studies. Int. Small Bus. J. 33 (6), 599-611.

Hjorth D. Steyaert, C. 2004. Narrative and Discursive Approaches in Entrepreneurship. Northampton, MA: Edward Elgar Publishing

Henderson, K. (1999) On Line and On Paper: Visual Represen- tations, Visual Culture and Computer Graphics in Design Engineering, MIT Press, Cambridge, MA.

Ingold, T. 2007. Lines: A brief history. London: Taylor \& Francis

Klee, P 1961/1978. The notebooks: Vol.1 The thinking eye. London: Lund Humphries.

Lakoff, G. Johnson, M. 1999. Philosophy in the flesh: The embodied mind and its challenge to Western thought. New York: Basic Books

McMullen, J. S. and Dimov, D. 2013. Time and entrepreneurial journey: The problems and promise of studying entrepreneurship as process. J. Manag Stud, 50(8), 1481-1512.

Merleau-Ponty, M. 1994. Eye and Mind in The Merleau-Ponty Aesthetics Reader. Translated and edited by Galen Johnsen and Michael Smith. Evanston, Il.: Northwestern University Press.

McMullen, J.S., Dimov, D., 2013. Time and the entrepreneurial journey: the problems and promise of studying entrepreneurship as a process. J. Manag. Stud. 50 (8), 14811512.

Meyer, A. D., 1991.Visual data in organizational research. Organ. Sci. 2(2), 218-236.

Nicholson, L. Anderson, A. R., 2005. News and nuances of the entrepreneurial myth and metaphor: Linguistic games in entrepreneurial sense-making and sense-giving. Enterp. Theory Pract. 29(2), 153-172.

Packard, M. 2017. Where did interpretivism go in the theory of entrepreneurship? J. Bus. Ventur. 32, 536-549. 
Pallasmaa, J., 2009. The Thinking Hand: Existential and Embodied Wisdom in Architecture. Wiley, Chichester.

Ramoglou, S., Tsang, E., 2016. A realist perspective of entrepreneurship: opportunities as propensities. Acad. Manage. Rev. 41 (3), 410-434.

Rosenberg, T. E. 2008. New beginnings and monstrous births: notes towards an appreciation of ideational drawing. In S. Garner Writing on Drawing: Essays on Drawing Practice and Research. Chicago: University of Chicago Press.

Schön, D.A. 1983. The Reflective Practitioner. Basic Books, New York.

Schumpeter, J. 1947. 'The creative response in economic history', Camb. J of Econ. 7(2): 149-159.

Shackle, G.L.S. 1979. Imagination and the Nature of Choice, Edinburgh University Press, Edinburgh.

Spinosa, C., Flores, F. Dreyfus, H.L. 1997. Disclosing New Worlds:

Entrepreneurship, Democratic Action and the Cultivation of Solidarity, MIT Press, Cambridge, MA.

Vince, R. and Broussine, M., 1996. Paradox, defense and attachment: Accessing and working with emotions and relations underlying organizational change. Organization Studies, 17(1): 1-21.

Vince, R and Warren, S. 2012- 'Participatory visual methods' in G Symon and C Cassell (ed.s) Qualitative Organizational Research. London: Sage. 275-295.

Wilson, F.R. 1999. The hand: How its use shapes the brain, language, and human culture. New York Pantheon.

Wolf, D. and Perry, M. D., 1988. From endpoints to repertoires: Some new conclusions about drawing development. J. Aesthetic Education, 22(2), 17-34.

Wright, S. (2007). Young children's meaning-making through drawing and 'telling': Analogies to filmic textual features. Australian Journal of Early Childhood, 32(4), $37-48$. 


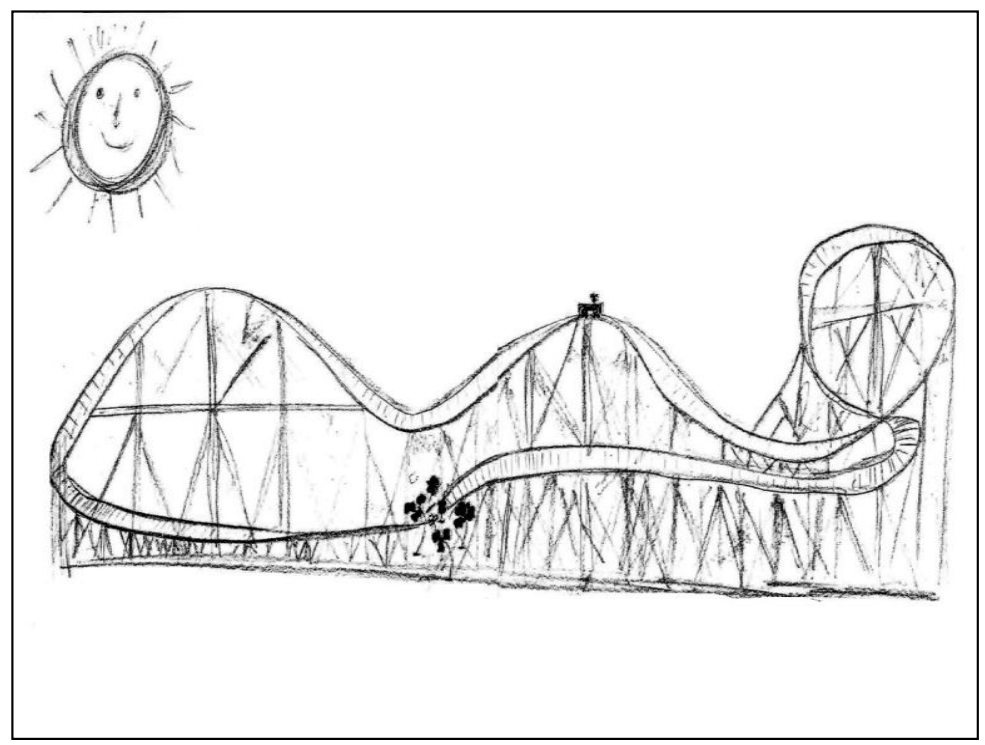

Image 1: Recruitment Entrepreneur - male

Image of the entrepreneur on a rollercoaster

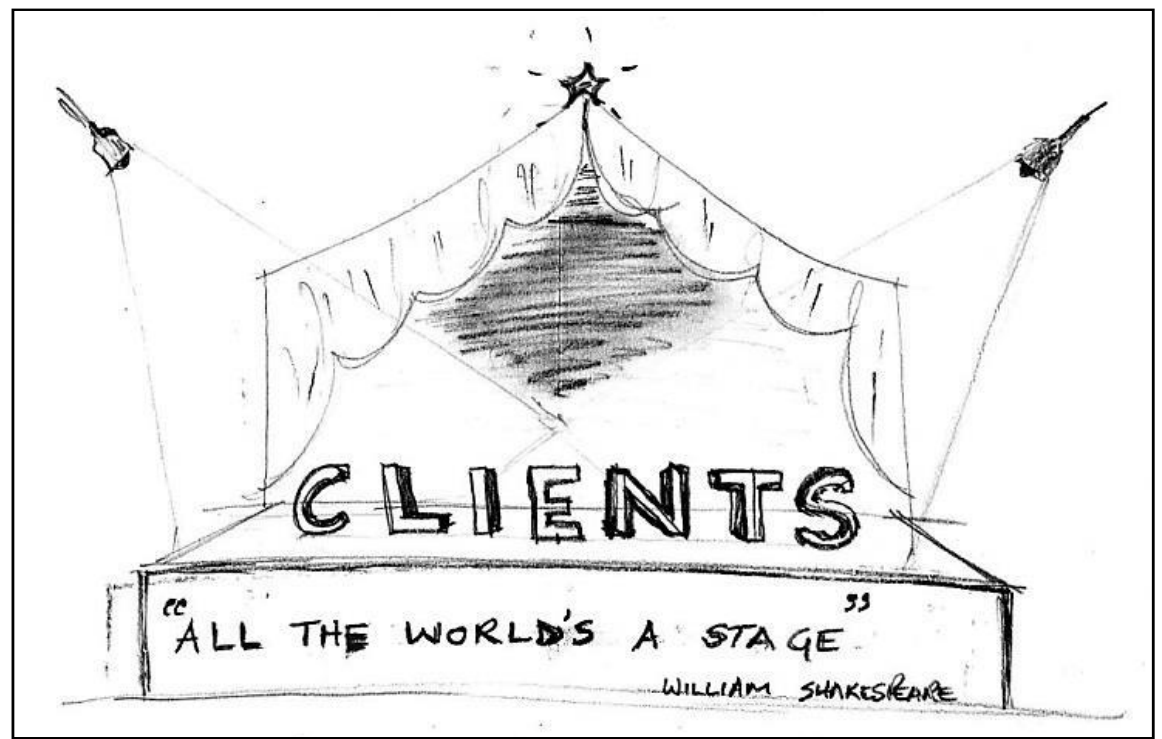

Image 2: Public Relations Entrepreneur - male

The word "clients" on a stage with the lights shining on the word 


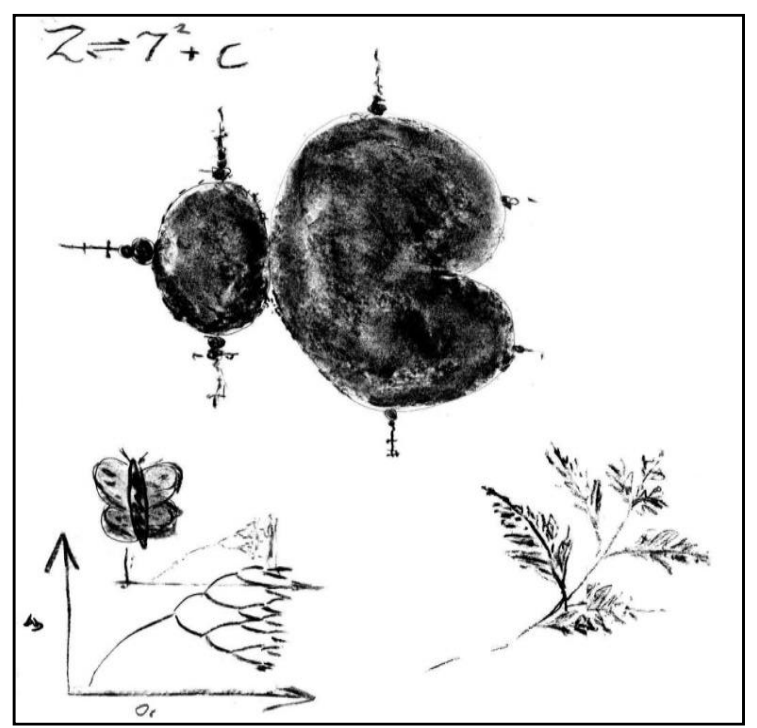

Image 3: IT Entrepreneur - male

'Mandelbrot set' (a mathematical equation related to Chaos Theory)

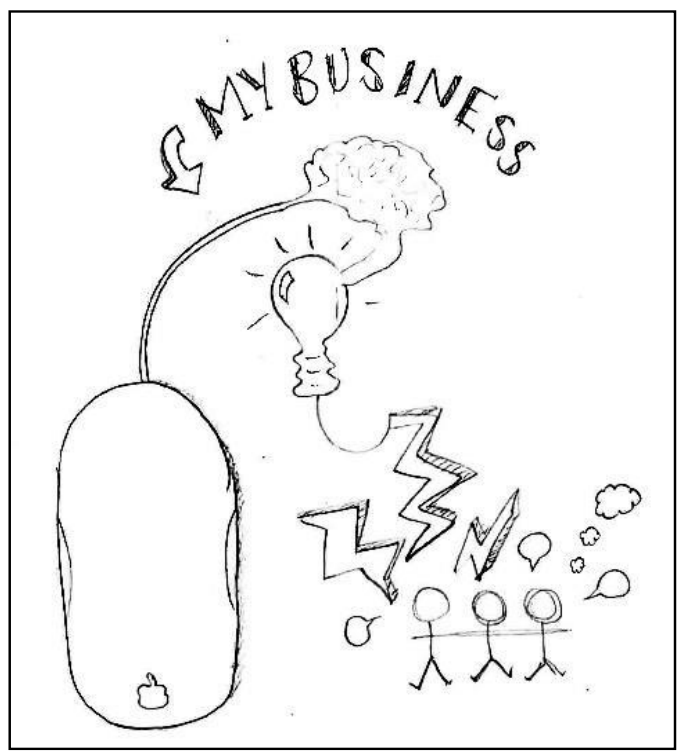

Image 4: PR and Communications Entrepreneur - female

An Apple computer mouse flowing into a brain and a light bulb with people underneath getting electrified with ideas through lighting bolts. 


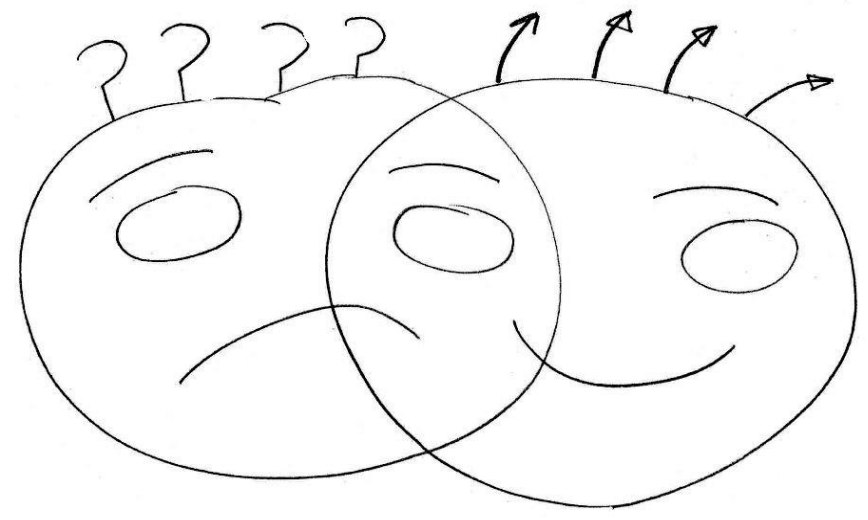

Image 5: Leadership Development Entrepreneur - male

Happy and sad faces interlinking (evoking the theatre symbol comedy/tragedy masks)

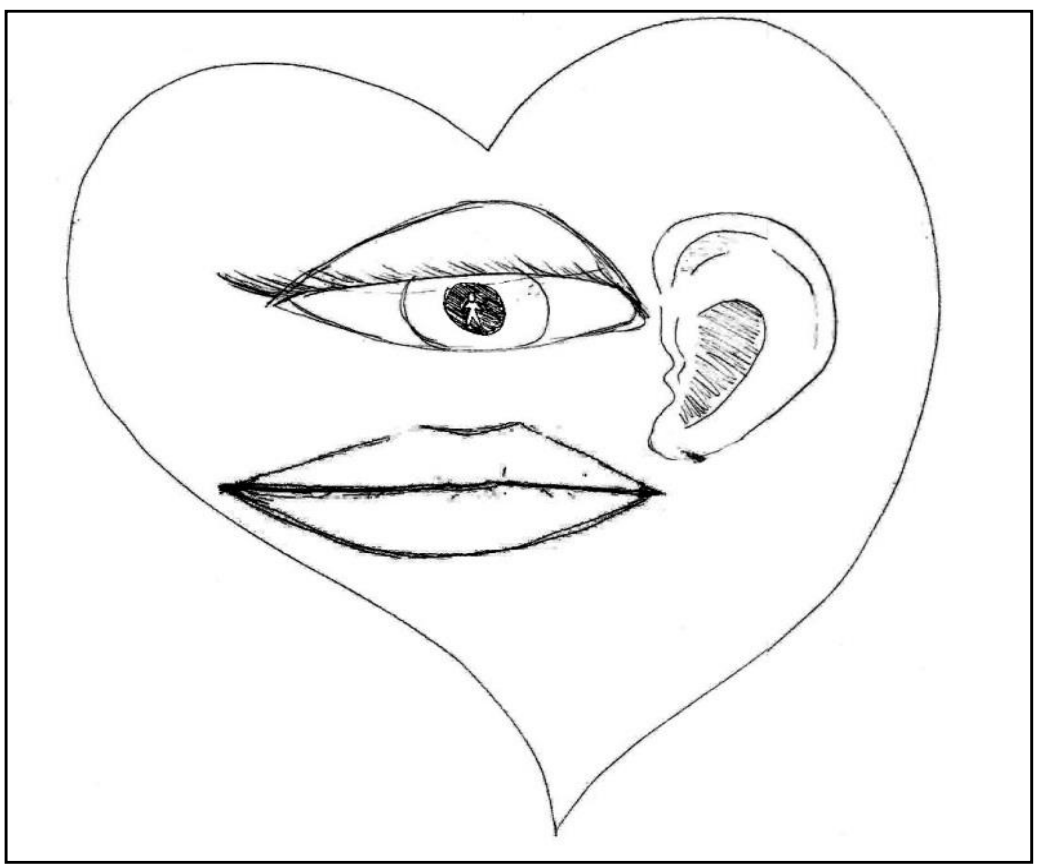


Image 6: Video production entrepreneur - female

'Mandelbrot set' (a mathematical equation related to Chaos Theory)

Lips, mouth and ear inside a heart shaped face 